\title{
PENGEMBANGAN GREEN TICKETING SEBAGAI UPAYA PENINGKATAN PENDAPATAN MASYARAKAT DAN PELESTARIAN EKOSISTEM WISATA PULAU TIBAN
}

\author{
Ade Rustiana $^{1 *}$, Nina Farliana ${ }^{1}$, Ubaedul Mustofa ${ }^{1}$ \\ ${ }^{1}$ Jurusan Pendidikan Ekonomi, Fakultas Ekonomi, Universitas Negeri Semarang, Semarang, Indonesia \\ *Penulis Korespodensi: ade_68ar@yahoo.com
}

\begin{abstract}
Abstrak
Pulau Tiban adalah objek wisata yang dikelola oleh Kelompok Sadar Wisata (Pokdarwis) Kartikajaya dan merupakan satu-satunya wisata pulau di Kabupaten Kendal yang menarik untuk dikunjungi. Permasalahan yang dihadapi Pokdarwis desa Kartikajaya adalah kurangnya kesadaran wisatawan dalam menjaga kelestarian alam lokasi wisata, kurangnya kemampuan manajerial tentang cara pengembangan wisata dengan mengedepankan kelestarian ekosistem yang ada, serta pengelolaan objek wisata yang masih sederhana. Tujuan kegiatan pengabdian ini yang pertama adalah untuk memberdayakan wisata Pulau Tiban Desa Kartikajaya, Kecamatan Patebon, Kabupaten Kendal melalui pengembangan green ticketing sebagai upaya pemberdayaan ekonomi masyarakat dan pelestarian ekosistem. Tujuan kedua adalah memberikan kontribusi positif dari adanya pemberdayaan Pokdarwis melalui pengembangan green ticketing, sehingga mampu memberikan nilai lebih tidak hanya pada lingkungan dan ekonomi, tetapi juga kesejahteraan masyarakat lokal. Metode pelaksanaan kegiatan pengabdian kepada masyarakat berupa pemberdayaan dan pengembangan green ticketing wisata yang dilakukan dengan metode pelatihan yang menghasilkan keterampilan, metode ceramah, tanya jawab, diskusi, simulasi serta pendampingan. Adapun hasil dari kegiatan pengabdian adalah meningkatkan wasasan dan pengetahuan baru pokdarwis desa Kartika jaya tentang pengelolaan wisata, meningkatkan kesadaran pokdarwis dan masyarakat terhadap kelestarian alam lokasi wisata dan adanya pemberdayaan pengembangan green ticketing.
\end{abstract}

Kata Kunci: Pulau Tiban, Green Ticketing, Ekowisata

\begin{abstract}
Tiban Island is a tourist attraction managed by Tourism Awareness Group (Pokdarwis) Kartikajaya and only one tourist island in Kendal Regency that is interesting to visit. The problem faced by Pokdarwis in Kartikajaya village is lack awareness of tourists in preserving the natural preservation of tourist sites, lack of managerial ability how to develop tourism by prioritizing the preservation of existing ecosystems, as well as managing simple tourist objects. The aim of service acticities, first is to empower the Tiban Island tourism in Kartikajaya Village, through the development of green ticketing as an effort to empower the community's economy and preserve the ecosystem. The second is make positive contribution to empowering Pokdarwis through the development of green ticketing, so as to provide usefullness not only to environment and economy, but also to the welfare of local communities. The method of implementing community service activities are empowerment and development of green ticketing tours is carried out by training methods that produce skills, lecture methods, discussion, simulation and mentoring. The results are increase the awareness and new knowledge Pokdarwis about tourism management, increase the awareness and the community towards the natural preservation of tourist sites and empower the development of green ticketing.
\end{abstract}

Keywords: Tiban Island, Green Ticketing, Ecotourism

\section{PENDAhUluan}

Kendal adalah salah satu kabupaten yang terletak di Provinsi Jawa Tengah. Kabupaten Kendal,

yang secara geografis terletak pada posisi $109^{\circ} 40^{\prime}$ $110^{0} 18^{\prime}$ Bujur Timur dan 6032'-7² $4^{\prime}$ ' Lintang Selatan. Secara administratif, wilayah Kabupaten Kendal berbatasan langsung dengan dan laut Jawa di utara, berbatasan dengan Kota Semarang di sebelah timur, berbatasan dengan Kabupaten Semarang dan Kabupaten Temanggung di sebelah selatan dan berbatasan dengan Kabupaten Batang di sebelah barat. Wilayah Kabupaten kendal terbagi menjadi 2 (dua) wilayah, yaitu bagian utara merupakan dataran rendah (pantai) dengan ketinggian antara 0-15 meter diatas 
permukaan laut dan daerah dataran tinggi yang terdiri atas tanah perbukitan hingga pegunungan dengan ketinggian antara 100-641 meter diatas permukaan laut (Badan Pusat Statistik Kabupaten Kendal, 2016)

Kabupaten Kendal yang merupakan dataran rendah (pantai) dan dataran tinggi menjadikan Kendal sebagai salah satu kabupaten yang bervariasi dalam pemanfaatan lahan yang ada. Karena berbatasan dengan laut dan daratan, maka ada beberapa wilayah yang berupa pantai, dan beberapa diantaranya

Tabel 1. Luas Penggunaan Lahan Kabupaten Kendal

\begin{tabular}{lll}
\hline \multicolumn{1}{c}{ Uraian } & \multicolumn{1}{c}{ Area $\left(\mathbf{k m}^{\mathbf{2}}\right)$} & \multicolumn{1}{c}{$\%$} \\
\hline Tanah Sawah & 259,64 & 25,91 \\
Tegalan & 203,13 & 20,27 \\
Perkebunan & 78,65 & 7,85 \\
Lain-lain & 460,81 & 45,98 \\
\hline Total & $\mathbf{1 0 0 0 2 , 2 3}$ & $\mathbf{1 0 0 , 0 0}$ \\
\hline
\end{tabular}

Sumber: (Badan Pusat Statistik Kabupaten Kendal, 2016)

Berdasarkan tabel 1 diperoleh informasi bahwa ada 45,98\% lahan di Kabupaten Kendal yang digunakan diluar bidang pertanian dan perkebunan. Salah satu pemanfaatan lahan yang ada yaitu dibidang pariwisata. Lokasi yang strategis menjadikan Kabupaten Kendal memiliki tempat yang potensial untuk tujuan wisata. Terdapat dua objek wisata di Kabupaten Kendal yang dikelola oleh Dinas kebudayaah dan Pariwisata Kabupaten Kendal, yaitu objek wisata pantai Sendang Sikucing di Kecamatan Rowosari dan Curug Sewu di Kecamatan Patean. Selain 2 (dua) objek wisata tersebut, masih terdapat sekitar 20 objek wisata lain yang dikelola mandiri oleh masyarakat lokal.

Salah satu tempat potensial wisata lain di Kabupaten Kendal adalah wisata Pulau Tiban, yang dikelola oleh masyarakat yang tergabung dalam Kelompok Sadar Wisata (Pokdarwis) Kartikajaya. Pulau Tiban yang termasuk dalam wilayah Desa Kartikajaya, Kecamatan Patebon, Kabupaten Kendal, adalah destinasi wisata yang kini mulai ramai dikunjungi wisatawan, khususnya wisatawan lokal. Lokasi pulau Tiban dari pusat Kota Kendal berjarak sektar 18 kilometer. Menurut penuturan warga setempat, disebut pulau Tiban karena awalnya dilokasi tersebut tidak dijumpai daratan yang menyembul ke permukaan.

Sekitar tahun 2014, pulau Tiban sudah benar-benar menampakkan dirinya sebagai sebuah daratan yang memanjang dari arah barat ke arah timur sepanjang hampir 1 kilometeran. Luas daratannya terus bertambah. Pada tahun 2014 pula, pulau Tiban secara resmi dibuka secara umum sebagai objek wisata. Warga yang tergabung ke Kelompok Sadar Wisata (Pokdarwis) Kartikajaya berupaya untuk terus mengembangkan pulau Tiban menjadi tujuan wisata yang layak dikunjungi. Pokdarwis merasa perlu untuk mengembangkan pulau Tiban menjadi objek wisata, karena selain bertujuan sebagai upaya pelestarian wilayah pantai Kartikajaya dari bahaya abrasi, dijadikan sebagai tempat yang sangat potensial di bidang pertanian, perkebunan, perikanan. Selain digunakan sebagai lahan pertanian, perkebunan maupun perikanan, beberapa luas lahan Kabupaten Kendal digunakan juga dibidang pariwisata, terutama daerah dataran rendah. Beberapa pantai di Kabupaten Kendal juga dimanfaatkan masyarakat untuk melaut mencari ikan. Luas penggunaan lahan di Kabupaten Kendal dapat dilihat pada tabel 1. keberadaan pulau Tiban bisa menjadi salah satu sumber tambahan penghasilan bagi warga setempat.

Wisata pulau Tiban yang merupakan objek wisata pulau satu-satunya di Kabupaten Kendal. Sejak dibuka, jumlah pengunjung wisata pulau ini mengalami kenaikan dari tahun ke tahun. Meningkatnya jumlah wisatawan membawa dampak positif sekaligus dampak negatif bagi kelestarian ekosistem pulau. Salah satu dampak positif dari bidang ekonomi yaitu bertambahnya pendapatan masyarakat. Dampak negatif yang ditimbulkan dari meningkatnya jumlah kunjungan wisatawan adalah menurunnya kualitas pertumbuhan ekosistem laut yang berada disekitar pulau, yang terlihat dari ketahanan hidup beberapa tanaman laut yang mampu hidup disekitar wilayah pulau sangat pendek.

Warga yang tergabung dalam Pokdarwis Kartikajaya selalu berupaya untuk melakukan pelestarian pulau dengan cara penanaman pohon yang memiliki ketahanan hidup cukup lama, diantaranya bakau dan cemara. Kegiatan tersebut rutin dilakukan Pokdarwis yang sekaligus sebagai pengelola wisata. Kegiatan penanaman pohon disekitar wilayah pantai juga melibatkan beberapa pihak luar, baik instansi pemerintah maupun swasta. Warga desa Kartikajaya juga melakukan upaya pembibitan pohon bakau untuk mempermudah dan penghematan biaya penyediaan bibit. Penyediaan bibit dalam penanaman bakau oleh instansi pemerintah maupun swasta bisa disediakan oleh warga desa Kartikajaya, atau kalau penanaman dalam jumlah besar diambilkan dari luar daerah Kartikajaya.

Keberadaan Pokdarwis dirasa sangat membantu sekali dalam penggalian potensi wisata dan pengembangan pariwisata yang menjadi potensi desa Kartikajaya. Sejak didirikannya Pokdrawis di tahun 2014, hingga saat ini telah berjalan dengan baik dengan melibatkan sebanyak 40 orang di dalam struktur organisasinya. 
Kepengurusan organisasi Pokdarwis juga telah berjalan baik dengan dibuktikan adanya pembagian kerja yang jelas dari masing-masing bagian di dalam proses pengelolaan lokasi wisata.

Saat ini Pokdarwis tersebut telah berhasil mengembangkan desa Kartikajaya sebagai desa wisata bahari. Salah satu destinasi wisata yang berhasil dikembangkan adalah wisata Pulau Tiban yang merupakan wisata pantai dan pulau kecil yang ada di desa Kartikajaya. Pokdarwis juga mendapat dukungan yang cukup besar dari masyarakat sekitar serta pemerintah desa dalam pengembangan pariwisata Pulau Tiban tersebut. Pokdarwis dan pemerintah desa hingga saat ini terus berusaha mengembangkan pariwisata Pulau Tiban tersbut dengan membuat program-program kreatif lainnya. Inilah yang menjadi dasar tim pengabdi melakukan kerjasama pengabdian dengan pokdarwis yang ada di desa Kartikajaya untuk mengimplementasikan green ticketing sebagai sistem pengembangan pariwisata dan pelestarian alam di area wisata.

Sumberdaya pulau Tiban merupakan potensi pembangunan ekonomi daerah Kendal. Oleh karena itu, optimalisasi potensi sumberdaya alam pulau terus dilakukan untuk memajukan pembangunan ekonomi daerah. Bagi pengelola kawasan wisata, pemasukan wisata menjadi salah sumber pendapatan. Pengelolaan ticketing menjadi prioritas untuk menjaga keberlangsungan ekonomi disekitar kawasan wisata. Disisi lain pengelolaan ticketing sebagai sarana untuk menjaga kelestarian ekosistem pulau. Guna mendukung terciptanya ekowisata pulau Tiban, salah satu upaya pelestarian sumberdaya alam pulau dan peningkatan ekonomi daerah yang dapat dikembangkan adalah konsep green ticketing.

Green ticketing adalah sebuah konsep yang memadukan sistem tiket masuk wisata dengan upaya pelestarian ekosistem pulau. Tiket masuk yang dibayarkan wisatawan tidak hanya diberikan dalam bentuk kertas sebagai tanda telah bayar, akan tetapi wisatawan juga akan mendapatkan sebatang pohon bakau, cemara ataupun jenis mangrove yang lain sebagai bukti kepedulian pelestarian lingkungan. Pohon tersebut yang nantinya akan ditanam di pulau Tiban untuk melindungi ekosistem pantai. Penyediaan bibit bakau dilakukan oleh kelompok sadar wisata (Pokdarwis) desa Kartikajaya yang bekerjasama dengan petani bakau setempat, sehingga ketersediaan bibit dapat dioptimalkan. Sehingga diharapkan akan ada hubungan timbal balik yang saling menguntungkan antara Pokdarwis dengan petani mangrove dan cemara.

Green ticketing adalah bagian dari pengembangan green business. Pengembangan konsep green ticketing adalah upaya untuk menumbuhkan kesadaran masyarakat terutama wisatawan terhadap kelestarian lingkungan. Wisatawan tidak hanya bisa menikmati keindahan alam tetapi juga berpastisipasi terhadap keberlangsungan makhluk hidup lainnya. Hal ini mengingat kesadaran masyarakat akan keberlangsungan sumber daya alam semakin berkurang. Konsumen semakin khawatir tentang kerusakan lingkungan dan lebih bersedia untuk membeli produk hijau, bukti empiris menunjukkan bahwa konsumen yang sadar lingkungan memiliki niat niat ke dalam perilaku pembelian yang sebenarnya (Co-operative Bank, 2011). Konsumen yang sadar lingkungan dapat didefinisikan sebagai konsumen yang mempertimbangkan konsekuensi lingkungan dari konsumsi pribadi mereka atau yang mencoba menggunakan kekuatan konsumsi mereka untuk membawa perubahan lingkungan (Barbarossa, C., \& Pastore, 2015). Peningkatan kesadaran dan sikap bukan merupakan peningkatan perubahan perilaku. Kenyataan menunjukkan bahwa hanya sedikit yang mau mengubah perilaku mereka; orang-orang yang memiliki kesadaran tinggipun bahkan belum tentu merubah perilaku mereka untuk sadar lingkungan (Cohen, S.A. and Higham, 2010), (Hares, A., Dickinson, J. and Wilkes, 2010), (McKercher, B., Prideaux, B., Cheung, C. and Law, 2010).

Bisnis hijau terlahir dari adanya kesadaran terhadap merebaknya kasus-kasus kerusakan lingkungan mulai dari yang kecil sampai ke tahap yang bersifat serius. Harapannya, dengan menerapkan konsep hijau maka aktifitas bisnis mulai dari produksi sampai barang jadi bahkan bagaimana memasarkannya, menjadi ramah lingkungan serta peduli sosial dan tetap mendapatkan uang. Menurut Kementrian Lingkungan Hidup dalam (Octavia, 2018) bahwa "Green business management" adalah strategi pengelolaan lingkungan yang terpadu yang meliputi pengembangan struktur organisasi, sistem dan budidaya dalam suatu kompetensi hijau dengan cara menerapkan dan mentaati seluruh peraturan tentang pengelolaan lingkungan, termasuk pengelolaan bahan baku, pengolahan limbah, penggunaan sumberdaya alam yang efektif, penggunaan teknologi produksi yang menghasilkan limbah minimal serta menerapkan komitmen kesadaran lingkungan bagi seluruh karyawan dalam organisasinya.

Sedangkan menurut (Sari, M. P., \& Raharja, 2018), "Greening Business Management" adalah strategi pengelolaan lingkungan yang terpadu yang meliputi pengembangan struktur organisasi, sistem dan budidaya dalam suatu kompetensi hijau dengan cara menerapkan dan mentaati seluruh peraturan tentang pengelolaan lingkungan, termasuk pengelolaan bahan baku, pengolahan limbah, penggunaan sumberdaya alam yang efektif, penggunaan teknologi produksi yang menghasilkan limbah minimal serta menerapkan komitmen kesadaran lingkungan bagi seluruh karyawan dalam organisasinya.

Konsep pengembangan green ticketing yang dimaksud disini adalah sistem ticketing dan upaya pelestarian 
sumber daya alam pantai, dimana sistem ticketing yang akan dikembangkan adalah tiket masuk wisata dengan menggunakan bibit bakau, cemara maupun jenis mangrove lainnya, yang nantinya akan wisatawan tanam diarea sekitar lokasi wisata sesuai panduan dari pengelola wisata. Bentuk permasalahan yang dihadapi secara umum adalah (1) sistem ticketing yang masih bersifat konvensional yaitu berupa selembar karcis sebagai bukti masuk, (2) keberlangsungan tanaman pantai yang hanya mampu bertahan hidup dalam waktu yang relatif pendek, sehingga harus dilakukan penanaman secara rutin untuk mengganti tanaman-tanaman yang rusak, baik dikarenakan ombak laut maupun ketahanan hidup tanaman yang bersangkutan, (3) Menurunnya kesadaran wisatawan dalam menjaga kelestarian sumber daya lokasi wisata. Hal ini terlihat dari masih ada sebagian wisatawan yang membuang sampah tidak pada tempatnya. (4) Fasilitas wisata yang tidak bisa bertahan lama dikarenakan pergerakan tanah dan gelombang laut yang menggeser keberadaan pulau, misalnya fasilitas toilet, yang terpaksa dipindah karena tanah lokasi toilet semula mengalami kerusakan akibat abrasi pantai.

Dari beberapa permasalahan yang dipaparkan, maka perlu dilakukan pengabdian masyarakat tentang pengembangan green ticketing sebagai upaya pemberdayaan ekonomi masyarakat dan pelestarian ekosistem pulau Tiban, Desa Kartikajaya, Patebon Kendal. Berdasarkan identifikasi diatas, dirumuskan masalah sebagai berikut.

1) Bagaimana proses pendampingan pengembangan green ticketing sebagai upaya pemberdayaan ekonomi masyarakat dan pelestarian ekosistem pulau Tiban, Desa Kartikajaya, Patebon Kendal?

2) Bagaimana kontribusi yang ditimbulkan dari adanya pengembangan green ticketing sebagai upaya pemberdayaan ekonomi masyarakat dan pelestarian ekosistem pulau Tiban, Desa Kartikajaya, Patebon Kendal?

Tujuan pengabdian kepada masyarakat ini adalah sebagai berikut.

1) Memberdayakan wisata Pulau Tiban Desa Kartikajaya, Kecamatan Patebon, Kabupaten Kendal melalui pengembangan green ticketing sebagai upaya pemberdayaan ekonomi masyarakat dan pelestarian ekosistem pulau Tiban.

2) Memberikan kontribusi positif dari adanya pemberdayaan pengembangan green ticketing, sehingga mampu memberikan nilai lebih tidak hanya pada lingkungan dan ekonomi, tetapi juga kesejahteraan masyarakat lokal.

Manfaat yang dapat diperoleh dari kegiatan ini adalah memberdayakan masyarakat dan Pokdarwis untuk dapat mengembangkan wisata Pulau Tiban melalui pengembangan green ticketing. Pengembangan konsep green ticketing Pulau Tiban ini diharapkan dapat meningkatkan pendapatan dan kesejahteraan masyarakat sekitar. Selain itu juga meningkatkan kesadaran masyarakat tentang pentingnya menjaga kelestarian sumber daya alam yang ada, sehingga keberlangsungan ekosistem laut dapat terjaga.

\section{METODE}

Kegiatan pengabdian ini ditujukan kepada kelompok sadar wisata (Pokdarwis) dan masyarakat, khususnya di desa Katikajaya, Patebon, Kendal. Model pemecahan masalah yang diterapkan oleh tim pengabdian kepada masyarakat adalah pendampingan yang menghasilkan keterampilan melalui diskusi, sosialisasi, dan pendampingan. Para Pokdarwis dan masyarakat desa Kartikajaya diharapkan mampu memahami dan memiliki pengetahuan serta keterampilan mengenai konsep pengembangan green ticketing wisata, untuk kemudian teraplikasikannya konsep green ticketing, sehingga mampu menjadi pilot project ticketing wisata lainnya, yang jangka panjangnya akan berkembangnya wisata pulau Tiban dengan keunikan sistem green ticketing.

Tim pengabdi melakukan kegiatan ditempat pengabdian sebanyak 3 kali dengan rincian kegiatan sebagai berikut.

1) Koordinasi awal, dilaksanakan pada awal bulan April 2017. Dalam kegiatan ini, tim pengabdi kepada masyarakat berkoordinasi untuk mengetahui sejauh mana gambaran umum pengetahuan masyarakat dan Pokdarwis mengenai konsep ticketing yang dilakukan selama ini dan potensi pengembangan green ticketing, dan bagaimana pengelolaan wisata yang selama ini telah dilakukan.

2) Pelaksanaan pemberdayaan keterampilan, transfer knowledge, sosialisasi, diskusi, dan dengan dilakukan pendampingan kegiatan. Kegiatan ini dilaksanakan pada waktu yang telah disepakati kedua belah pihak. Pendampingan kegiatan dilakukan guna mengetahui keberlanjutan pengembangan green ticketing wisata.

3) Monitoring dan pendampingan berkala. Monitoring dan pendampingan berkala dilakukan setelah masyarakat sudah mampu memahami konsep green ticketing wisata, dan berkembangnya pulau Tiban yang memiliki karakteristik green ticketing wisata. Kegiatan ini dilakukan guna mengawasi keberlanjutan program kegiatan serta semakin berkembangnya potensi alam desa Kartikajaya.

Realisasi pelaksanaan model pengabdian adalah pemberian materi tentang pengetahuan dan keterampilan pengelolaan objek wisata melalui konsep green ticketing wisata. Hal tesebut dikarenakan melihat kondisi umum dilokasi, masyarakat dan Pokdarwis masih memiliki kekurangmampuan keterampilan dalam melakukan berbagai inovasi guna 
meningkatkan kunjungan wisatawan dengan tetap mengedepankan kelestarian ekosistem pantai serta meningkatkan pendapatan masyarakat. Sistem ticketing yang umum dilakukan dan fasilitas yang terbatas, menyebabkan pemenuhan pelayanan wisata kurang maksimal. Harapannya dengan adanya pengabdian ini, Pokdarwis dan masyarakat mampu menampilkan performansi yang lebih baik dalam mengelola dan mengembangkan ekowisata pulau Tiban, yang muaranya akan meningkatkan kesejahteraan masyarakat dan terjaganya kelestarian alam desa Kartikajaya serta meningkatkan kesadaran wisatawan untuk peduli terhadapat lingkungan. Adapun alur kegiatan pengabdian dijelaskan pada gambar 1 .

Identifikasi masalah :

1. Kurangnya kemampuan manajerial tentang cara pengembangan potensi wisata dengan konsep ekowisata.

2. Pengelolaan objek wisata yang masih sederhana, terutama sistem ticketing .

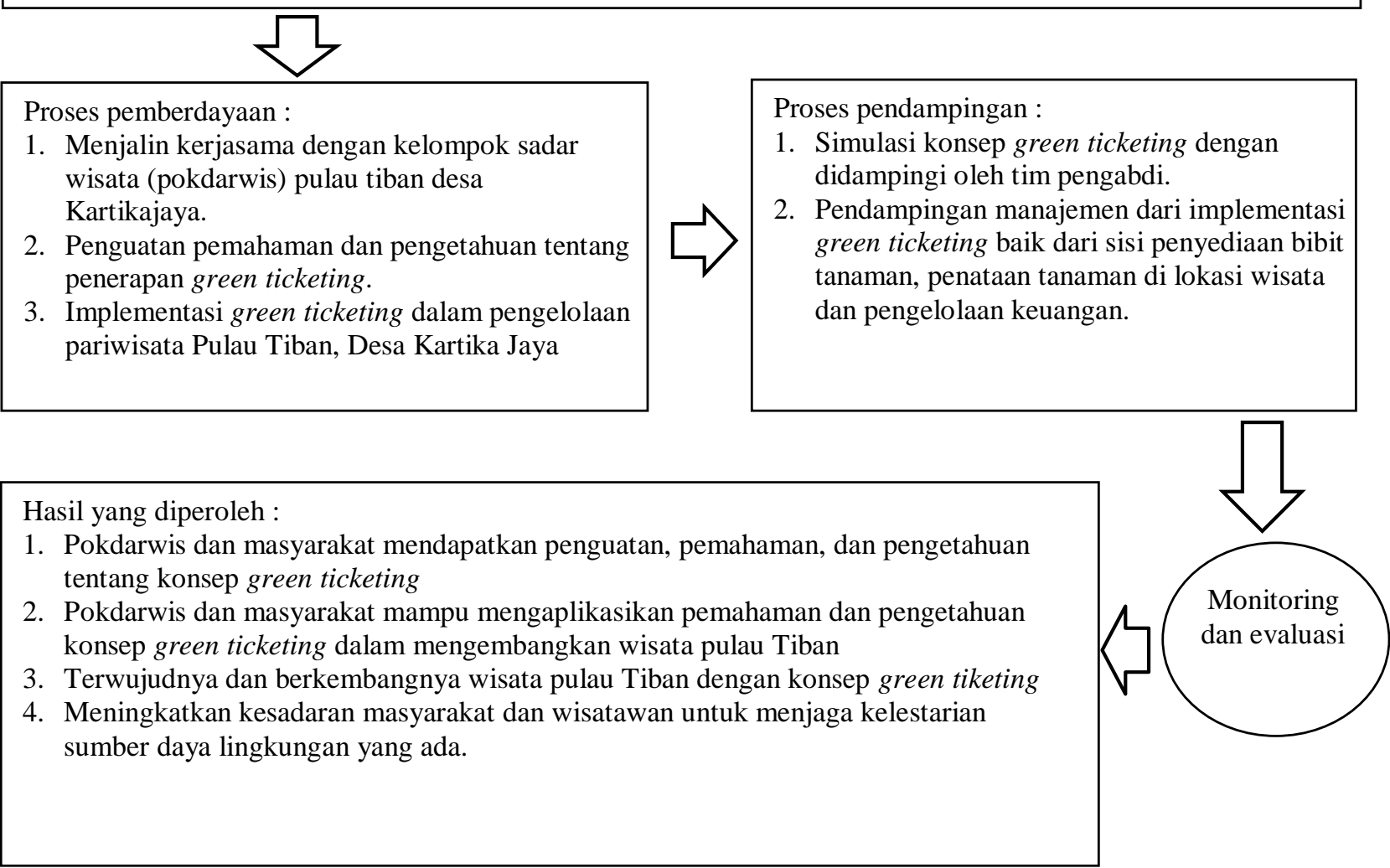

Gambar 1. Bagan Kerangka Pemecahan Masalah

Kegiatan pengabdian kepada masyarakat berupa pemberdayaan dan pengembangan green ticketing wisata pulau Tiban yang dilakukan dengan metode ceramah, tanya jawab, diskusi, simulasi serta pendampingan. Adapun langkah-langkah strategis yang bisa pengabdi rumuskan dapat dijelaskan dalam flowchard pada gambar 2. Khalayak sasaran yang dituju dalam pengabdian ini adalah Pokdarwis dan masyarakat desa Kartikajaya, Patebon Kendal yang akan mengembangkan green ticketing wisata. Partisipasi mitra dilakukan dengan cara mengikuti pendampingan dan mendengarkan paparan materi terkait dengan konsep green ticketing wisata kemudian dilanjutkan dengan terlibat dalam simulasi green ticketing wisata pulau Tiban. 
Langkah 1 :

Pokdarwis dan masyarakat Desa Kartikajaya akan diberikan wawasan tentang manfaat mengembangkan potensi daerah
Langkah 2 :

Pokdarwis dan masyarakat desa Kartikajaya diberikan pengetahuan dan pemahaman untuk mengembangkan ekowisata pulau Tiban berbasis green ticketing
Langkah 4 :

Memberikan gambaran dan simulasi tentang penerapan dan pengembangan ekowisata Pulau Tiban dengan berbasis green ticketing
Langkah 3 :

Sesi diskusi dan tanya jawab dengan memberikan kesempatan kepada Pokdarwis dan masyarakat untuk bertanya terkait implementasi green ticketing di Pulau Tiban

Langkah 5 :

Melakukan pendampingan kepada Pokdarwis dan masyarakat dalam menerapkan dan mengembangkan konsep ekowisata berbasis green ticketing di pulau Tiban

Gambar 2. Langkah Strategis Penerapan Green Ticketing di Pulau Tiban, Desa Kartikajaya, Patebon, Kendal

\section{HASIL DAN PEMBAHASAN}

Hasil kegiatan pengabdian pada masyarakat mengacu kepada langkah strategis pengembangan green ticketing wisata pulau tiban, desa Kartikajaya, Patebon, Kendal seperti pada gambar 1. Hasil kegiatan dijelaskan kedalam beberapa rincian hasil kegiatan berikut ini.

1) Kordinasi dan Pemetaan Potensi Wisata

Kegiatan koordinasi dilaksanakan di lokasi wisata pulau Tiban yaitu desa Kartikajaya, Patebon Kendal pada hari Jumat, tanggal 27 April 2018. Koordinasi dilakukan dengan sekretaris Pokdarwis Kartikajaya. Topik pembahasaan koordinasi terkait dengan kondisi terkini wisata yang meliputi perkembangan jumlah wisatawan, kendala yang belum terselesaikan, strategi pemasaran dan partisipasi pemerintah daerah.

Berdasarkan kegiatan koordinasi yang dilakukan, diperoleh berbagai informasi yaitu kondisi pulau tiban sendiri sebagai salah satu pulau yang masuk kategori baru terbentuk sedang mengalami pergeseran tanah karena gelombang pasang air laut yang tinggi, sehingga menyebabkan beberapa tanaman pantai mati dan tenggelamnya pinggiran pulau. Dengan kondisi tersebut menyebabkan penurunan jumlah wisatawan. Wisawatan tidak bisa menikmati keindahan pulau sampai tenggelamnya matahari, karena pulau harus ditutup jam 15.00 WIB dikarenakan gelombang air laut yang tinggi. Kondisi seperti ini sudah biasa berlangsung sejak pulau Tiban terbentuk apabila masuk bulan Maret sampai Juli. Kondisi tanah akan kembali normal apabila sudah melewati bulan Juli. Hal ini menjadi pekerjaa besar bagi Pokdarwis untuk terus berupaya menjaga kestabilan strukturan tanah di pulau Tiban, sehingga tanah tidak semakin tergerus gelombang air laut. 


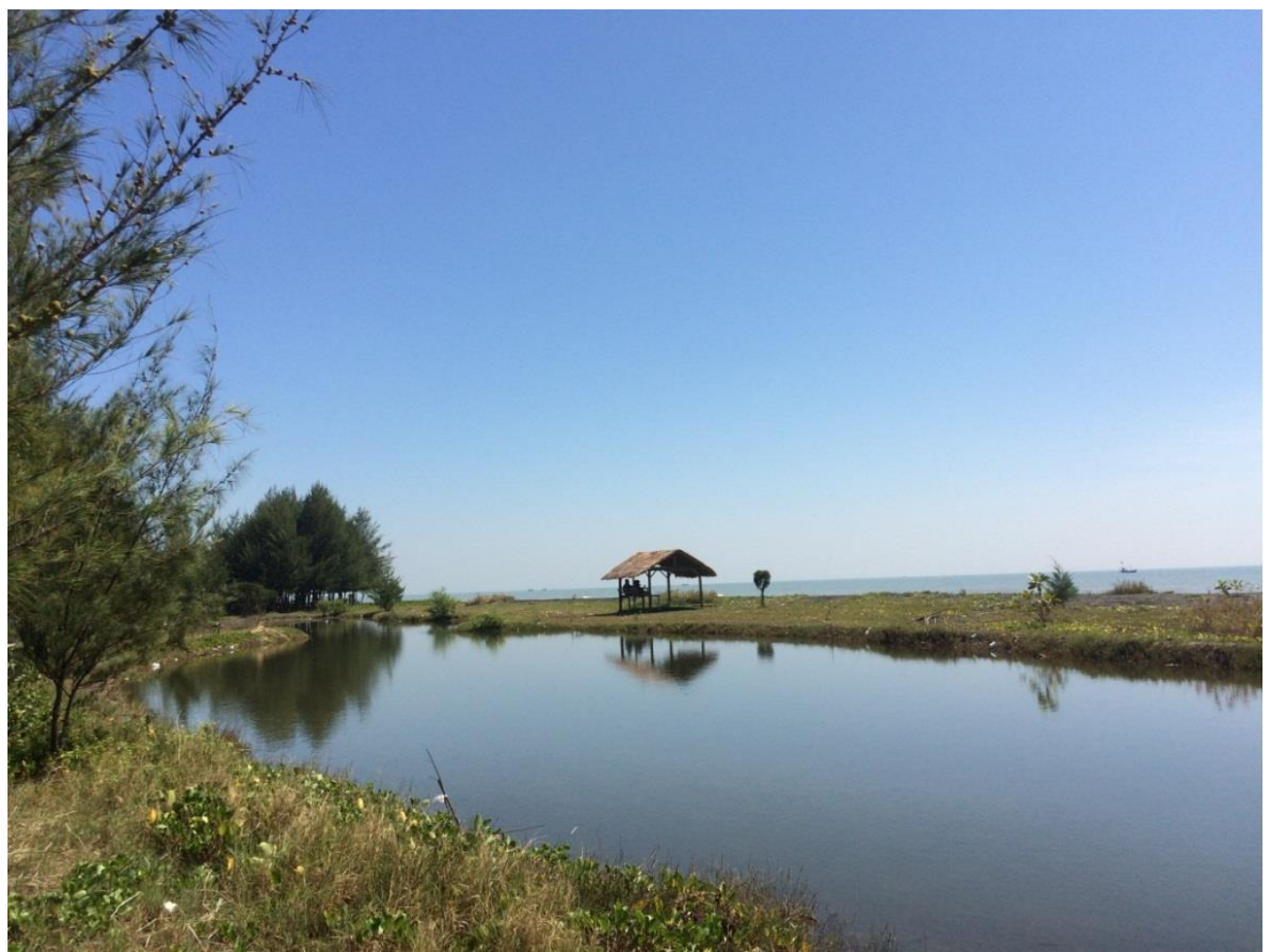

Gambar 3. Kondisi Tanah di Pulau Tiban

Upaya pelestarian terus dilakukan oleh Pokdarwis agar kestabilan tanah dan ekosistem tetap terjaga. Salah satu upaya yang dilakukan adalah penanaman rutin mangrove disekitar area pulau. Penanaman mangrove dilakukan tidak hanya oleh Pokdarwis, tetapi juga instansi pemerintah daerah dan lembaga swadaya masyarakat (LSM) yang dengan suka rela berpartisipasi mengembangkan wisata daerah. Pokdarwis membuka kesempatan kepada siapa saja yang ingin ikut berpartisipasi dalam penanaman pohon, dikarenakan kebutuhan akan tumbuhkembangnya pohon menjadi bagian penting demi kelangsungan keberadaan pulau Tiban. Ketika melakukan koordinasi dengan pengelola pulau Tiban, tim pengabdian mendapat kesempatan untuk menyaksikan penanaman mangrove yang dilakukan oleh salah satu organisasi kemasyarakatan.

\section{2) Sosialisasi dan Focus Grup Discussion (FGD)}

Hasil kegiatan yang merupakan program pengabdian tahap selanjutnya adalah sosialisasi dan focus grup discussion (FGD) pengembangan green ticketing kepada pokdarwis, masyarakat sekitar dan pemerintah daerah serta lembaga terkait. Sosialisasi dilakukan pada hari Rabu, 11 Juli 2018. Hal ini dilakukan mengingat kesepakatan dan kesesuaian jadwal tim pengabdi dengan pengola wisata pulau Tiban. Sosialisasi dan FGD wisata juga dilakukan kepada pemerintah daerah agar pemerintah turut andil dalam proses kebijakan pengembangan wisata pulau Tiban. Pelaksanaan sosialisasi dilakukan dengan metode penyampaian materi secara paaralel dan diperdalam dengan FGD.
Kegiatan sosialisasi dibuka oleh kepala desa kartikajaya dan ketua tim pengabdian. Kemudian dilanjutkan paparan materi oleh para ahli dibidangnya, meliputi pemberian pengantar dan materi tentang pengembangan green ticketing di pulau tiban yang disampaikan oleh bapak Drs. Ade Rustiana, M.Si selaku ketua tim pengabdi dan disambung materi kedua tentang manajemen pemasaran wisata berbasis ramah lingkungan yang disampaikan oleh bapak Kemal Budi Mulyana, S.Pd., M.Pd.

Kegiatan sosialisasi ini bekerjasama dengan pemerintah desa serta kelompok sadar wisata (pokdarwis) Kartikajaya. Adapun peserta dari kegiatan sosialisasi dihadiri oleh Pokdarwis Kartika Beach, Ketua RT dan RW, serta perangkat Pemerintah Desa,. Kegiatan dibuka oleh kepala desa Kartikajaya yang kemudian dilanjutkan dengan sambutan dari tim pengabdi yang diwakili oleh Bapak Drs. Ade Rustiana, M.Si dan dilanjutkan penyerahan kenang-kenangan dari tim pengabdi kepada kepala desa dan perwakilan pokdarwis.

Setelah itu dilanjutkan pada acara inti yakni penyampaian materi oleh dua narasumber yakni Bapak Drs. Ade Rustiana M.Si dan Bapak Kemal Budi Mulyana, S.Pd., M.Pd. Berdasarkan hasil penyampaian oleh pemateri dapat disimpulkan bahwa implementasi pariwisata berbasis ramah lingkungan atau yang dikenal dengan istilah green tourism ini cukup penting. Dikarenakan dengan implementasi wisata berbasis ramah lingkungan tersebut selain masyarakat mendapatkan manfaat secara aspek ekonomi dan finansial juga akan menjaga 
keberlangsungan ekosistem di area wisata yang sekaligus akan menjadi daya tarik bagi pengunjung. Selain itu juga konsep wisata berbasis lingkungan saat ini sedang menjadi trend bagi kalangan wisatawan. Sebagaimana yang sudah dikembangkan di beberapa daerah wisata lainnya.

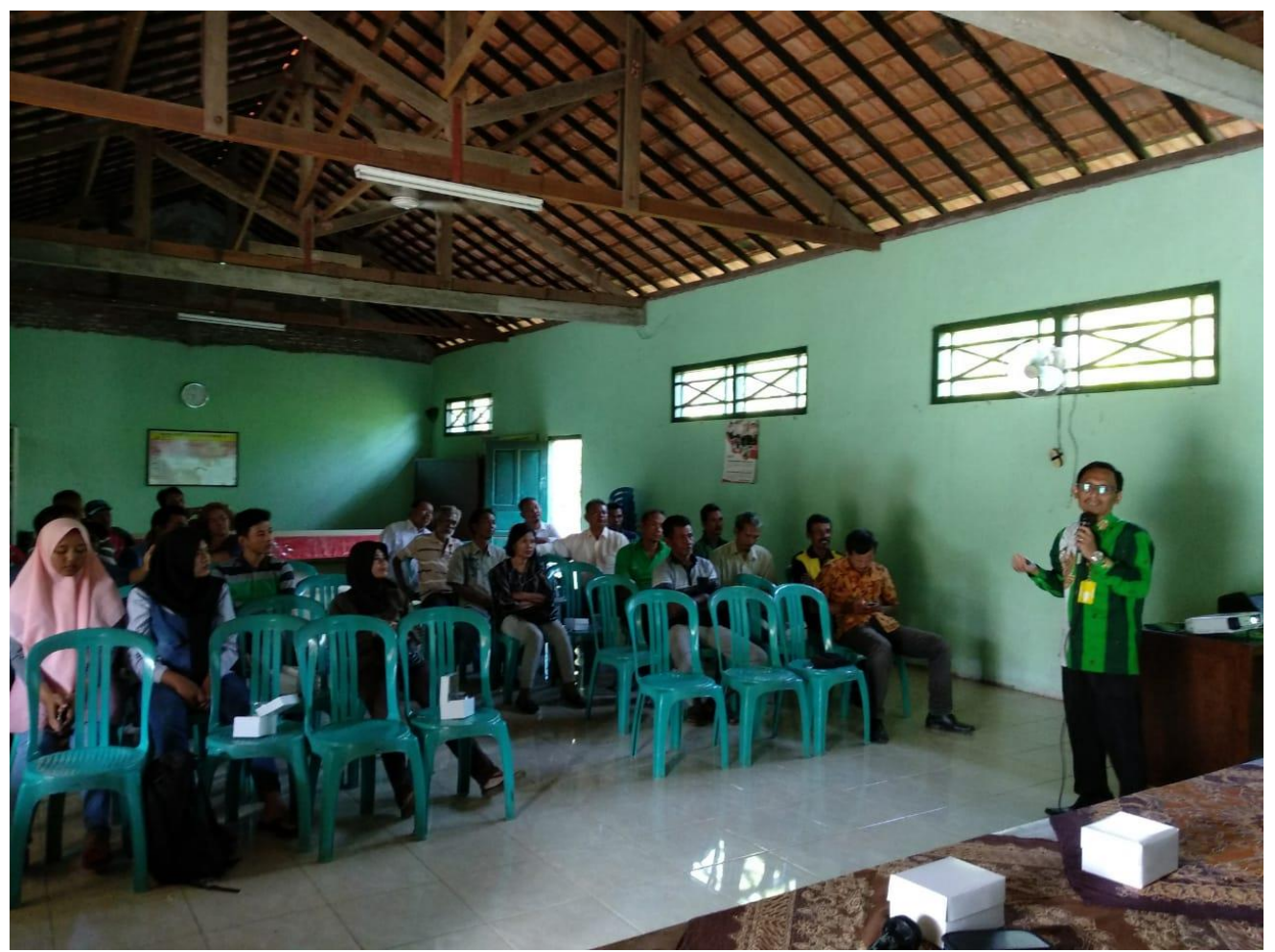

Gambar 4. Penyampaian Materi Pengembangan Konsep Green Ticketing oleh Tim Pengabdi

Uniknya, konsep green ticketing ini merupakan bagian dari salah satu bentuk green tourism yang ternyata belum banyak yang mengembangkan bahkan berdasarkan penelusuran tim pengabdi belum ada tempat wisata yang benar-benar menerapkan system ini. Sehingga harapannya jika konsep green ticketing ini berhasil diterapkan, maka wisata pualu tiban desa Kartikajaya akan menjadi satu-satunya dan yang pertema menerapkan konsep tersebut. Sehingga hal ini menjadikan motivasi tersendiri dan ketertarikan pokdarwis terhadap materi yang disampaikan oleh tim pengabdi.

Materi sosialisasi kedua disampaikan oleh bapak Kemal Budi Mulyana, S.Pd., M.Pd dengan tema manajemen dan pemasaran wisaata berbasis ramah lingkungan. Dari materi yang disampikan peserta diberikan gambaran dan contoh lokasi-lokasi wisata di daerah jawa tengah yang telah menerapkan konsep green tourism seperti wisata Mangrove Tapak di Semarang. Wisata tersebut relatif masih baru yang cukup banyak diminati yang menawarkan konsep eduwisata penanaman dan jelajah hutan bakau di tepi pantai.

Konsep green tourism berupa eduwisata hutan mangrove yang ada di Tapak tersebut menurut pemateri dianggap sebagai salah satu contoh yang bisa diterapkan di wisata pulau tiban dikarenakan karakteristik lokasinya memiliki kesamaan. Selain itu juga pemateri memberikan contoh lain lokasi wisata yang menerapkan konsep green tourism yang sebenarnya sangat sederhana namun cukup efektif untuk menarik wisatwana. Seperti wisata taman bunga yang ada di beberapa daerah yang sedang berkembang saat ini seperti desa wisata Sri Gunung di Kabupaten Batang. Konsepnya sangat sederhana hanya sekedar memoles lahan kosong dengan tanaman bung-bunga yang berwarna-warni sehingga bisa menjadi spot foto atau selfie. Wisata pulau tiban dianggap juga memiliki potensi yang yang yakni menarik minat wisatawan dengan cara memrindah area pulau yang tidak berawa dengan tanaman bunga-bunga.

Setelah peserta diberikan materi oleh tim pengabdi, untuk memantapkan konsep dan rencana implementasi dari konsep green ticketing tersebut maka peserta diarahkan untuk melakukan Focus Group Discussion (FGD) diantara anggota pokdarwis dan tim pengabdi. Dari hasil FGD tersebut dapat disimpulkan bahwa pada dasarnya baik Pokdarwis maupun pemerintah desa sangat tertarik dengan konsep green ticketing tersebut. Harapannya konsep tersebut benar-benar bisa diterapkan mengingat kondisi tempat wisata pulau Tiban yang membutuhkan upaya penghijaun untuk meminimalisir terjadinya rob air laut yang selama ini terjadi. Pada dasarnya Pokdarwis telah melakukan upaya penanaman di Pulau Tiban tersebut namun proses penanaman masih dilakukan secara mandiri oleh Pokdarwis itu sendiri yang dirasa kurang optimal dan banyak kendala. Namun penerapan konsep green ticketing tersebut menurut Pokdarwis perlu disiapkan 
secara matang terkait segala sesuatunya termasuk persiapan sumber daya manusia, ketersediaan tanaman dan juga manajemen penanamannya.

Pokdarwis berharap langkah untuk mewujudkan konsep green ticketing ini harus secara terus menerus diupayakan dan perlu pendampingan dari tim pengabdi. Harapannya ada tindak lanjut kerjasama yang lebih intensif lagi agar konsep green ticketing ini bisa benar-benar terlaksana.

\section{3) Pendampingan Pasca Sosialisasi}

Program pendampingan pasca sosialisasi adalah pelatihan manajemen dan pemasaran wisata berbasis green ticketing. Kegiatan ini merupakan tindak lanjut dari program pengabdian sebelumnya. Pelatihan manajemen dan pemasaran ditujukan kepada Pokdarwis. Pelatihan manajemen dan pemasaran wisata berbasis green ticketing ini perlu dilakukan mengingat potensi dari wisata pulau tiban ini cukup bagu namun masih kurang menarik minat wisatawan dikarenakan tempat wisata tersebut belum terkelola dengan baik

Dari sisi manajemen, pengabdi melakukan pendampingan dalam bentuk peningkatan sumber daya manusia dan manajemen lokasi Pulau Tiban dengan mencontoh beberapa tempat wisata yang memiliki karakteristik yang sama, salah satunya adalah memberikan contoh manajemen pariwisata di lokasi yang ada di Jawa Tengah seperti eduwisata hutan mangrove di Tapak Semarang dan Wisata bunga Sri Gunung di Batang. Pulau tiban memiliki karakteristik yang sama, yaitu cukup potensial untuk menjadi wisata yang juga sekaligus menjadi ajang edukasi penanaman bakau. Sehingga pendampingan yang dilakukan oleh tim pengabdi kepada Pokdarwis adalah memastikan masyarakat yang memiliki lahan atau tambak yang memiliki tanaman bakau untuk bisa ikut berpartisipasi dalam program tersebut.

Pendampingan selanjutnya adalah memastikan agar impelementasi dari green ticketing tersebut benarbenar bisa berjalan dengan cara memantau perkembangan jumlah tanaman yang ada di pulau tiban apakah ada penambahan tanaman atau tidak. Adapun penanaman tahap awal adalah penanaman tanaman yang kecil-kecil termasuk bakau maupun bunga-bunga di area Pulau Tiban. Sehingga harapannya dari waktu ke waktu ada perubahan baik jumlah tanaman maupun visualisasi dari pulau Tiban itu sendiri, yang awalnya gersang menjadi lebih hijau dan indah karena adanya penambahan tanaman dan bunga-bunga.

Selain itu juga pendampingan pengembangan green ticketing pulau Tiban adalah terkait aspek pemasarannya. Pemasaran dianjurkan dilakukan secara masif baik melalui sistem konvensional (pamflet, selebaran, maupun iklan-iklan cetak lainnya) juga tim pengabdi memastikan pemasaran dilakukan melalui dunia maya seperti Facebook, Instagram, maupun media sosial lainnya. Apalagi wisata pulau tiban telah memiliki akun resmi media sosial baik Facebook maupun Instagram, sehingga harapannya bisa lebih efektif sebagai media pemasaran wisata pulau tiban.

Secara umum pelaksanaan kegiatan pengabdian pengembangan green ticketing sebagai upaya peningkatan pendapatan masyarakat dan pelestarian ekosistem wisata pulau Tiban, Patebon Kendal berjalan lancar dan mendapat sambutan antusias dari peserta yaitu Pokdarwis Kartikajaya. Hal ini ditunjukkan dengan banyaknya anggota Pokdarwis yang datang mengikuti program pengabdian tersebut. Selain itu dukungan dari pemerintah daerah dan instansi lain juga sangat positif.

Namun masih terdapat kekurangan dan beberapa evaluasi yang perlu dilakukan terkait program pengabdian tersebut. Salah satunya adalah program pengembangan green ticketing ini membutuhkan waktu yang cukup lama untuk benar-benar bisa diterapkan karena membutuhkan persiapan yang matang termasuk sumber daya manusia, manajemen maupun pemasarannya. Harapannya pengabdian akan terus dilanjutkan sebagai bentuk pendampingan terhadap Pokdarwis. Konsep green ticketing ini merupakan upaya-upaya konservasi dengan penanaman bakau dan tanaman-tanaman lain yang membutuhkan juga support dari pemerintah desa maupun pemerintah daerah. Evaluasi selanjutnya adalah pengabdian ini perlu mengajak dan menggandeng lebih banyak pihak, mulai dari warga hingga pengurus kelurahan dan unsur-unsur lainnya sehingga lebih terintegratif dan menyatukan visi dan misi.

Dari hasil pengabdian yang telah dilakukan ada beberapa kendala yang perlu dibenahi dalam pengembangan green ticketing di Pulau Tiban diantaranya yaitu terkait sumber daya manusia dalam pengelolaan wisata Pulau Tiban. Sebagian besar anggota Pokdarwis berusia 40 tahun keatas. Hal ini mengakibatkan keterbatas kemampuan dalam pengembangan konsep green ticketing di Pulau Tiban. Yang dibutuhkan adalah sumber daya dari kalangan remaja yang memiliki kemampuan dan inovasi terkini dalam pengembangan wisata.

Kontribusi kegiatan pengabdian pengembangan green ticketing di Pulau Tiban, Desa Kartikajaya, Patebon Kendal adalah pertama, memberikan pengetahuan kepada masyarakat, terutama kelompok sadar wisata (Pokdarwis) dalam pengelolaan wisata. Wisata yang sudah ada bisa dikembangkan secara lebih efektif dan lebih potensial dengan cara yang lebih unik salah satunya dengan penerapan konsep green ticketing. Kedua, meningkatkan kesadaran masyarakat sekitar dan para wisatawan akan pentingnya nilai-nilai konservasi lingkungan terutama pentingnya menanam 
pohon. Ketiga, terjaganya ekosistem yang ada di pulau tiban serta terjaganya pantai dari abrasi air laut yang terus terjadi. Keempat, menarik wisatawan untuk berkunjung ke pulau Tiban dengan panorama indahnya laut didukung dengan kesejukan dan keindahan pohon-pohon yang ditanam di area pulau Tiban.

Selain itu, hasil dari pengabdian selain memberikan manfaat kepada internal desa, wisatawan juga diharapkan bias memberikan mafaat yang lebih luas kepada masyarakat luar. Untuk itu dalam pengabdian ini, tim pengabdi mencoba untuk mempublikasikan hasil dari pengabdian tersebut melalui media sehingga informasi adanya kegiatan dan bentuk pengabdian ini juga tersampaikan ke masyarkat luas, sekaligus menjadi salah satu luaran dari kegiatan pengabdian ini. Adapun publikasi yang dilakukan salah satunya adalah melalui website Fakultas Ekonomi Universitas Negeri Semarang yang terbit pada 6 Agustus 2018.
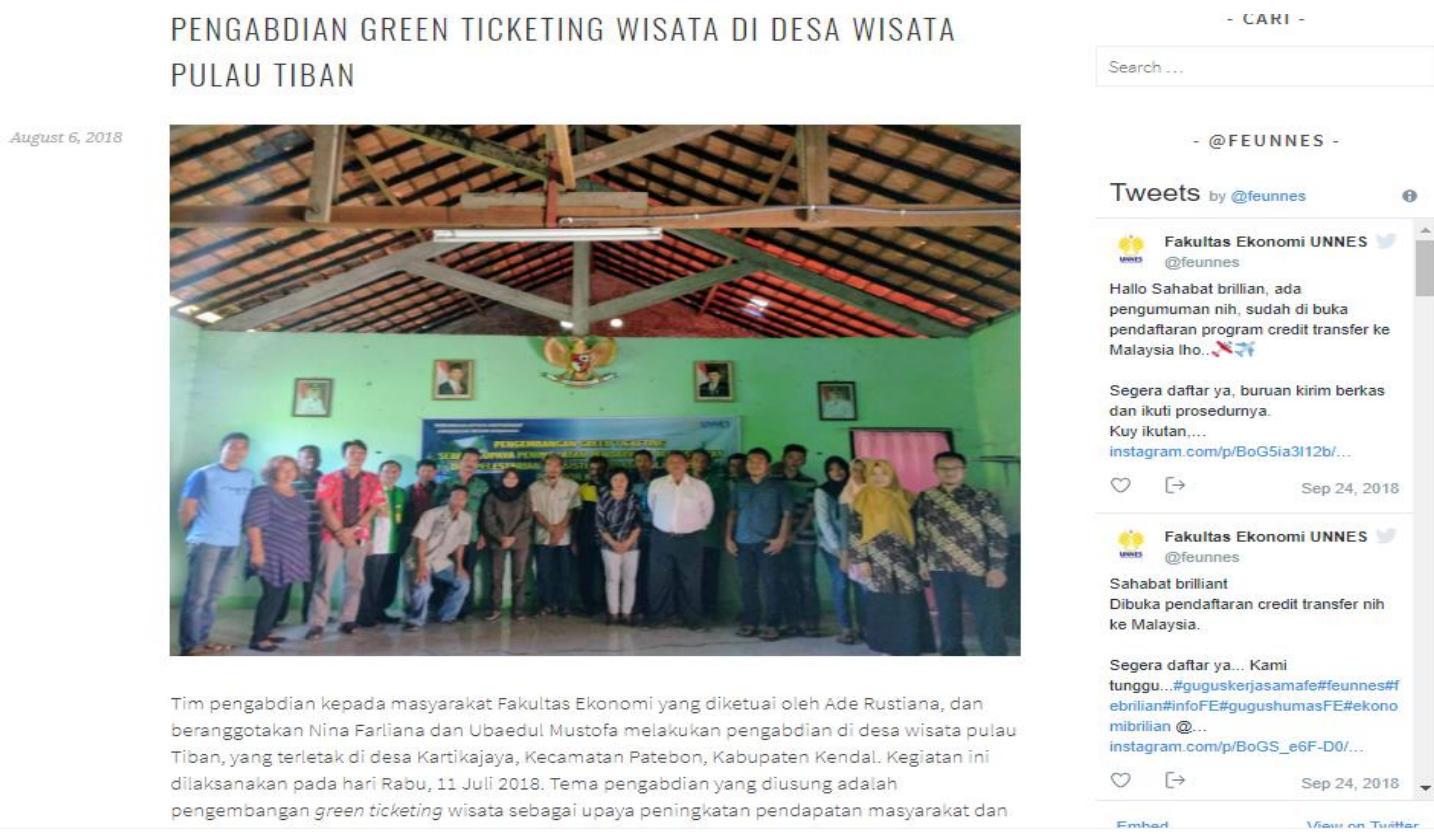

Gambar 5. Screenshoot Bukti Publikasi Pengabdian Melalui Website FE UNNES

Selain dipublikasikan melalui website Fakultas Ekonomi Universitas Negeri Semarang, agar para wisatawan lebih mudah untuk mencari informasi mengenaik objek wisata Pulau Tiban, maka telah disediakan website pulau tiban dengan alamat URL http://wisatatiban.com/

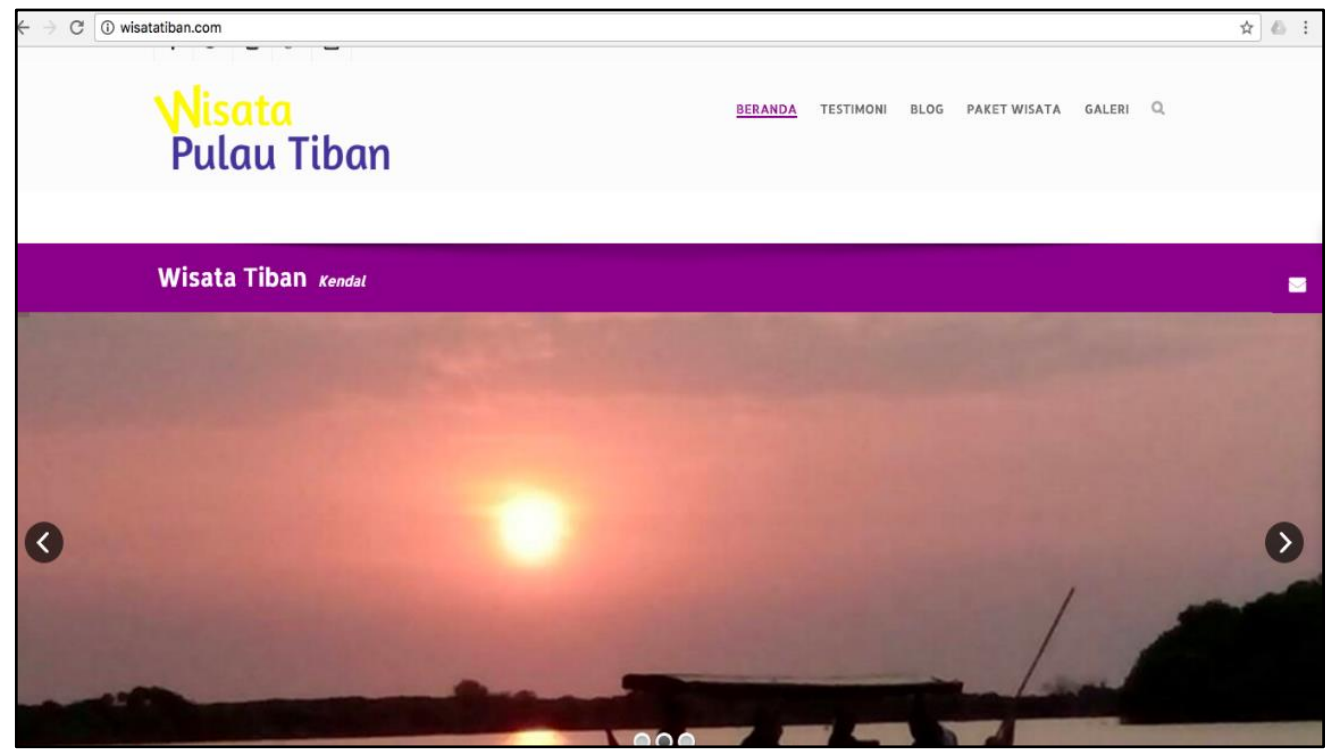

Gambar 6. Screenshoot Website Wisata Pulau Tiban 
Proses publikasi tidak berhenti disitu aja, karena dari publikasi di web tersebut, tim pengabdi terus membagikan informasi atau berita tersebut ke masyarakat umum dengan mengirimkan link berita dari web tersebut. Sehingga informasi berita tersebut lebih mudah tersebar kepada masyarakat. Dengan adanya publikasi lewat media tersebut harapnnya bisa meberikan informasi dan manfaat yang lebih luas kepada masyarakat umum, desa wisata maupun penggerak pariwisata lain seperti pokdarwis di desadesa. Sekaligus memberikan inspirasi kepada mereka untuk juga berinovasi dan berkreasi dalam mengembangkan potensi pariwisata yang ada di desa masing-masing.

\section{KESIMPULAN}

1) Teknis pelatihan dan pendampingan optimalisasi pengorganisasian wisata pulau Tiban pada Pokdarwis Desa Kartikajaya, Patebon Kendal dimulai dengan tahap koordinasi dan identifikasi struktur organisasi wisata pulau Tiban, kegiatan sosialisasi optimalisasi pengorganisasian berbasis media, pelatihan dan pendampingan, simulasi dan evaluasi program pengabdian.

2) Kontribusi yang ditimbulkan dari adanya pengembangan green ticketing wisata pulau Tiban adalah memberikan pengetahuan kepada masyarakat, terutama kelompok sadar wisata (Pokdarwis) dalam pengelolaan wisata, meningkatkan kesadaran masyarakat sekitar dan para wisatawan akan pentingnya nilai-nilai konservasi lingkungan terutama pentingnya menanam pohon, terjaganya ekosistem yang ada di pulau Tiban serta terjaganya pantai dari abrasi air laut yang terus terjadi, menarik wisatawan untuk berkunjung ke pulau Tiban dengan panorama indahnya laut didukung dengan kesejukan dan keindahan pohon-pohon yang ditanam di area pulau Tiban.

\section{UCAPAN TERIMA KASIH}

Ucapan terima kasih ditujukan kepada pemberi dana yaitu Lembaga Penelitian dan Pengabdian Kepada Masyarakat (LP2M) Universitas Negeri Semarang tahun 2018, serta Kelompok Sadar Wisata (Pokdarwis) Kartikajaya, seluruh masyarakat desa Kartikajaya dan pemerintah desa Kartikajaya, Kecamatan Patebon, Kabupaten Kendal. Ucapan terima kasih juga disampaikan kepada seluruh anggota tim pengabdian kepada masyarakat atas kerja keras dan kerjasamanya sehingga artikel ini bisa selesai tepat waktu.

\section{DAFTAR PUSTAKA}

Badan Pusat Statistik Kabupaten Kendal. (2016). Statistik Kabuptaen Kendal 2016. Retrieved from https://kendalkab.bps.go.id/

Barbarossa, C., \& Pastore, A. (2015). Why environmentally conscious consumers do not purchase green products: a cognitive mapping approach. Qualitative Market Research: An International Journal, 18(2), 188-209.
Cohen, S.A. and Higham, J. E. . (2010). Eyes wide shut? UK consumer perceptions on aviation climate impacts and travel decisions to New Zealand. Current Issues in Tourism, 12 No. 1, $1-19$.

Co-operative Bank. (2011). Ethical consumerism report. Retrieved from www.goodwithmoney.co. uk/ethicalconsumerism-report-2010

Hares, A., Dickinson, J. and Wilkes, K. (2010). Climate change and the air travel decisions of UK tourists'. Journal of Transport Geography, Vol. 18 No, pp. 466-73.

McKercher, B., Prideaux, B., Cheung, C. and Law, R. (2010). Achieving voluntary reductions in the carbon footprint of tourism and climate change. Journal of Sustainable Tourism, Vol. 18 No, pp. 297-317.

Octavia, D. (2018). Analisa Lingkungan Makro, Perilaku Konsumen Serta Peluang Dan Strategi Bisnis Hijau Di Indonesia. In In Conference In Business, Accounting, And Management (CBAM) (p. Vol. 1, No. 1, pp. 165-174).).

Sari, M. P., \& Raharja, S. (2018). Implementasi Konservasi Moral Melalui Pendidikan Akuntansi Berkarakter Untuk Mengoptimalkan Peran Etika Bisnis Dan Profesi Dalam Upaya Mewujudkan Greening Business Management. In Conference In Business, Accounting, And Management (CBAM) (p. Vol. 1, No. 2, pp. 663-683). 